\title{
Nuclear DNA content, chromatin organization and chromosome banding in brown and yellow seeds of Dasypyrum villosum (L.) P. Candargy
}

\author{
R. CREMONINI*, N. COLONNA†, A. STEFANI $\dagger$, I. GALASSO $\ddagger$ \& D. PIGNONE \\ Dipartimento di Scienze Botaniche, Università di Pisa, Via L. Ghini 5, 56126 Pisa, tScuola Superiore Studi Universitari e

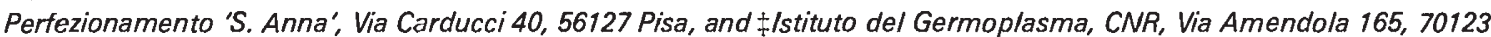 \\ Bari, Italy
}

\begin{abstract}
Banding patterns of metaphase chromosomes and nuclear DNA content in root meristematic cells of yellow and brown seeds of Dasypyrum villosum were determined. Microdensitometric evaluation of nuclear absorptions at different thresholds of optical density after Feulgen reaction indicated the organization of the chromatin in interphase nuclei, and allowed an evaluation of the amount of heterochromatin. These results were compared with those obtained after the application of banding techniques.
\end{abstract}

Keywords: chromatin organization, chromosome banding, Dasypyrum villosum, fluorochromes, kernels.

\section{Introduction}

Many species closely related to Triticum are known to have agronomic characters that make them interesting for wheat improvement, and many studies have been carried out on the possibility of introducing alien genes into cultivated wheats (Knott, 1987).

The genus Dasypyrum includes two Mediterranean wild species: an annual outcrossing diploid, Dasypyrum villosum (L.) P. Candargy (formerly Haynaldia villosa Schur.), and a perennial tetraploid, Dasypyrum breviaristatum (Lindb. f.) Frederiksen (formerly Dasypyrum hordeaceum Candargy), with basic chromosome number $x=7$ (Frederiksen, 1991).

The genome of Dasypyrum villosum was designated as V by Sears (1953) and it is considered an important source of genes for powdery mildew resistance $(\mathrm{De}$ Pace et al., 1988) and seed storage protein content and quality (Della Gatta et al., 1984; Blanco \& Simeone, 1988).

D. villosum produces two types of caryopses in the same ear: yellow (yellow 246; Seguy, 1936) and brown (red 112; Seguy, 1936) seeds. The inheritance of the seed colour does not show any dominance effect, nor does it follow Mendelian segregation. Mature plants developed from the two types of seeds do not show

${ }^{*}$ Correspondence. evident morphological differences; both of them are able to produce ears with yellow and brown caryopses (Stefani \& Onnis, 1983).

A different behaviour of seed germination and viability during ripening and ageing (Meletti \& Onnis, 1961; Stefani \& Onnis, 1983; De Gara et al., 1991) and a different duration of the mitotic cycle (Innocenti \& Bitonti, 1983) have been reported for the two types of caryopses.

Analyses of interphase nuclei chromatin organization, using densitometric determinations at different thresholds of optical density and of chromosome heterochromatin distribution, by means of C-banding and the fluorochromes Hoechst 33258, Chromomycin $\mathrm{A}_{3}$ (CMA)/4',6-diamidino-2-phenylindol-dihydrochloride (DAPI) and Ag-NOR staining, were applied in order to characterize the different fractions of the nuclear genome.

In this paper we report on (1) nuclear DNA content, (2) chromatin organization and (3) chromosome banding patterns in root meristems from seedlings from the two types of caryopses.

\section{Materials and methods}

Seeds of a natural population of $D$. villosum, collected in Campobasso (Italy), have been propagated for eight years in the experimental fields of the Department of 
Botanical Sciences in San Piero a Grado (Pisa). Seeds harvested in 1991 were soaked in running tap water overnight and yellow and brown caryopses were germinated in $12 \mathrm{~cm}$ Petri dishes in an incubator at $22 \pm 1^{\circ} \mathrm{C}$ in the dark.

For cytophotometric analyses, $1 \mathrm{~cm}$ long root tips were fixed in ethanol:acetic acid $(3: 1 \mathrm{v} / \mathrm{v})$. Squashes were made under a coverslip in a drop of 45 per cent acetic acid after treatment with a 5 per cent aqueous solution of pectinase (Sigma) for $1 \mathrm{~h}$ at $37^{\circ} \mathrm{C}$, with the addition of $0.001 \mathrm{~m}$ EDTA in order to inhibit the activity of DNase, if present (Berlyn et al., 1979). After coverslips had been removed by the dry-ice method, squashes were hydrolysed in $1 \mathrm{~N} \mathrm{HCl}$ at $60^{\circ} \mathrm{C}$ for 7 min and stained by Feulgen reagent. After staining the slides were subjected to three $10 \mathrm{~min}$ washes in $\mathrm{SO}_{2}$ water prior to dehydration and mounting in DPX (Fluka). In addition, squashes of the shoot tips were made in order to compare the nuclear DNA content in the two meristematic regions of the seedlings and squashes of secondary root meristems were also made. Squashes of root tips of Vicia faba were concurrrently stained for each group of slides and were used as internal standards. Absorptions measured in $V$. faba preparations were also used to convert relative Feulgen arbitrary units into picograms of DNA.

Feulgen DNA absorptions in individual cell nuclei in postsynthetic condition (G2 phase), were measured at $550 \mathrm{~nm}$ using a Leitz MPV3 integrating microdensitometer equipped with a Halogen-Bellaphot lamp (Osram).

With the same instrument and at the same wavelength, the Feulgen DNA absorptions of chromatin fractions with different condensation levels were measured in the same nucleus, after selecting different thresholds of optical density in the instrument according to the methods of Havelange and Jeanny (1984) and Cremonini et al. (1992). The instrument reads all parts of the nucleus where the optical density is greater than the preselected limit, and treats the parts below this limit as a clear field. The results of this analysis are reported as the percentage of Feulgen absorption in comparison with the initial value of 100 . Data processing of the curves obtained was carried out by integral calculation according to Simpson's rule.

For chromosome banding, actively growing roots were excised and treated for $24 \mathrm{~h}$ with ice cold distilled water in order to accumulate metaphases. These were then fixed for $24 \mathrm{~h}$ in ethanol:acetic acid $(3: 1, \mathrm{v} / \mathrm{v})$. Root tip meristems were squashed under coverslips in a drop of 45 per cent acetic acid and coverslips were removed by the dry-ice method.

C-banding, Ag-NOR and fluorochrome staining were performed according to Giraldez et al. (1979),
Bloom \& Goodpasture (1976) and Galasso \& Pignone (1991), respectively. Slides stained with CMA were counterstained with DAPI. A Leitz Aristoplan microscope fitted with epiluminescence was used: the filter combination A was used to observe Hoechst 33258 (H33258) staining; on the same metaphase, filter block E3 was used to observe CMA fluorescence, and filter block A was used to observe DAPI staining.

\section{Results}

\section{Cytophotometry}

The mean Feulgen absorptions of $4 \mathrm{C}$ interphase nuclei, nuclear DNA content and the surface area are listed in Table 1.

DNA content differs from one type of caryopsis to the other: $23.7 \mathrm{pg}$ for the yellow caryopses and $19.1 \mathrm{pg}$ for the brown ones in $4 \mathrm{C}$ interphase nuclei (Table 1 ). In each type of caryopsis we analysed 20 nuclei from each of five seedlings and carried out an analysis of variance on the subsequent data (Table 2). Differences in the DNA content of primary root nuclei occur between seedlings within each type of caryopsis. However, no significant difference in the nuclear DNA content of early prophase exists between primary and secondary root tips or between apical and root meristems of the same seedling (data not reported).

In order to assess whether some chromatin fractions were involved in cytophotometric differences between the two types of caryopsis, measurements were taken from interphase nuclei at different thresholds of optical density. Interphase nuclei in each type, having absorption values corresponding to $4 \mathrm{C}$ and the same surface area, were chosen and the results are reported in Table 3 and in Fig. 1. While the Feulgen absorption of brown seeds is reduced to zero at optical density threshold 21 , the Feulgen absorption of yellow seeds is reduced to zero at the higher threshold of optical density 24 .

A mathematical elaboration based on Simpson's rule, allows the determination of the point of inflexion of the two curves optimized from the experimental data. This point ( 9 for yellow and brown caryopses) makes it possible to discriminate two areas in each curve. While the values of the first areas of the caryopses are similar (454 and 448, for yellow and brown, respectively), the values of the second areas are different in the two types of caryopses, 229 and 184 for yellow and brown, respectively (Table 4).

\section{Metaphase chromosomes}

The general karyotype of $D$. villosum is analogous to the one reported by Gill (1981), Friebe et al. (1987), 
Table 1 Feulgen absorptions (arbitrary units; mean \pm S.E.), DNA content in early prophase nuclei, and surface area of interphase nuclei $(4 \mathrm{C})$ in the root meristems of the two types of caryopsis of Dasypyrum villosum; Feulgen absorption and surface area are the mean of 100 determinations of interphase nuclei ( 20 nuclei for each of five seedlings)

\begin{tabular}{lccc}
\hline Caryopses & $\begin{array}{c}\text { Feulgen absorption of } \\
\text { 4C interphase nuclei } \\
\text { (a.u.; mean } \pm \text { S.E. })\end{array}$ & $\begin{array}{c}\text { Mean DNA } \\
\text { content per } \\
\text { 4C nuclei }(\mathrm{pg})\end{array}$ & $\begin{array}{c}\text { Mean surface area } \\
\text { of 4C interphase } \\
\text { nuclei }\left(\mu \mathrm{m}^{2} \pm \text { S.E. }\right)\end{array}$ \\
\hline Yellow & $2615 \pm 32.4$ & 23.7 & $330 \pm 4.7$ \\
Brown & $2033 \pm 25.1$ & 19.1 & $249 \pm 3.0$ \\
\hline
\end{tabular}

Table 2 Feulgen absorption (arbitrary units, mean \pm S.E.) and corresponding nuclear DNA content of early prophases $(4 \mathrm{C})$ in the root meristems of five yellow and brown caryopses of Dasypyrum villosum; each Feulgen absorption is the mean of 20 early prophases for each seedling

\begin{tabular}{|c|c|c|c|c|}
\hline $\begin{array}{l}\text { Root } \\
\text { type }\end{array}$ & \multicolumn{2}{|c|}{$\begin{array}{c}\text { Feulgen absorption } \\
\text { (a.u., mean } \pm \text { S.E. })\end{array}$} & \multicolumn{2}{|c|}{$\begin{array}{c}\text { Nuclear DNA content } \\
(\mathrm{pg})\end{array}$} \\
\hline \multicolumn{5}{|l|}{$\begin{array}{l}\text { Yellow } \\
\text { seedlings }\end{array}$} \\
\hline $\begin{array}{l}1 \\
2 \\
3 \\
4 \\
5\end{array}$ & $\begin{array}{l}2449.2 \\
2443.0 \\
2425.5 \\
2410.3 \\
2293.7\end{array}$ & $\begin{array}{l}32.9 \\
+34.5 \\
+31.6 \\
+34.0 \\
+33.5\end{array}$ & $\begin{array}{l}24.17 \\
24.11 \\
23.94 \\
23.79 \\
22.64\end{array}$ & \\
\hline \multicolumn{5}{|l|}{$\begin{array}{l}\text { Brown } \\
\text { seedlings }\end{array}$} \\
\hline $\begin{array}{l}1 \\
2 \\
3 \\
4 \\
5\end{array}$ & $\begin{array}{l}2026.2 \\
1923.1 \\
1830.4 \\
1818.5 \\
1745.0\end{array}$ & $\begin{array}{r}41.4 \\
+43.3 \\
+23.9 \\
+29.5 \\
+33.5\end{array}$ & $\begin{array}{l}20.80 \\
19.74 \\
18.79 \\
18.66 \\
17.91\end{array}$ & \\
\hline $\begin{array}{l}\text { Source of } \\
\text { variation }\end{array}$ & d.f. & $\begin{array}{l}\text { Sum of } \\
\text { squares }\end{array}$ & $\begin{array}{l}\text { Mean } \\
\text { squares }\end{array}$ & $F$ \\
\hline $\begin{array}{l}\text { Caryopsis colou } \\
\text { Error } \\
\text { Total }\end{array}$ & ur $\begin{array}{r}1 \\
198 \\
199\end{array}$ & $\begin{array}{l}14520121.6 \\
28908000.0 \\
43428121.6\end{array}$ & $\begin{array}{lr}6 & 14520121.6 \\
0 & 146000.0 \\
6 & \end{array}$ & $99.4 *$ \\
\hline
\end{tabular}

*Significant at $P \leq 0.01$.

Grilli et al. (1988) and Linde-Laursen \& Frederiksen (1991). The techniques of differential chromosome staining allowed the identification of each pair of chromosomes. The general karyotypes of the two types of caryopsis were very similar and only a few differences were observed. A large amount of chromosomal heterochromatin was observed using C-banding (Fig. 2 ); the chromosomal distribution of this heterochro- matin was slightly variable between brown and yellow caryopses and, to some extent, between chromosomes of the same pair. H33258 staining allowed the identification of only a part of the C-bandable heterochromatin; the distribution of this fraction was more uniform (Fig. 2). In addition only the NOR region was identified with both CMA/DAPI and Ag-NOR staining (Fig. 3).

To avoid confusion with previously reported karyotypes, the seven pairs of chromosomes were indicated with small Roman numerals from i to vii.

Chromosome i. This has proved to be the most variable chromosome, showing differences in the two types of caryopsis and also heteromorphism within the chromosome pair. The short arm is quite constant, having two very close telomeric C-bands which are H33258-positive. However, two centromeric C-bands are present on only one chromosome of the pair in both yellow and brown types. The long arm of the yellow type, after C-banding, shows a subcentromeric band and two telomeric bands; after H33258 staining on the same arm two close telomeric bands are present. Conversely, in the brown type, the long arm of the first homologue shows a subcentromeric and a subtelomeric C-band with only the second being H33258positive. Only the long arm of the second homologue shows two close telomeric C-bands and only the proximal reacts positively to $\mathrm{H} 33258$.

Chromosome ii. The short arm shows a telomeric and somewhat heteromorphic C-band in both yellow and brown types. Several intercalary bands are present around the centromere, some of which show heteromorphism in the yellow type. After H33258 staining, a telomeric band is visible in both types. In addition, a centromeric band is observed on one homologue in the yellow type only. The long arm is characterized by a large subtelomeric C-band which is clearly seen after H33258 staining in both yellow and brown types. This chromosome resembles the $\mathrm{D}(4 \mathrm{H})$ of Friebe et al. (1987). 
Table 3 Percentage of Feulgen absorption (arbitrary units; mean \pm S.E.) at different thresholds of optical density of $4 \mathrm{C}$ interphase nuclei $(\mathrm{G} 2)$ in five seedlings for each kind of caryopsis of Dasypyrum villosum (20 nuclei for each seedling were measured); areas (from integral calculation by Simpson's rule) of each gap between thresholds of optical density and their ratios are reported

\begin{tabular}{|c|c|c|c|c|c|}
\hline \multirow{3}{*}{$\begin{array}{c}\text { Thresholds } \\
\text { of optical } \\
\text { density }\end{array}$} & \multicolumn{4}{|c|}{ Feulgen absorption $(\%)$} & \multirow{3}{*}{$\begin{array}{l}\text { Ratio } \\
\text { between } \\
\text { areas }\end{array}$} \\
\hline & \multicolumn{2}{|c|}{ Yellow } & \multicolumn{2}{|c|}{ Brown } & \\
\hline & $\%$ & Area & $\%$ & Area & \\
\hline 3 & 100 & & 100 & & \\
\hline 6 & $75.0+1.0$ & 265.5 & $74.4+11$ & 264.6 & 1.00 \\
\hline 9 & $51.1 \pm 1.7$ & 189.1 & $48.2 \pm 1.4$ & 183.9 & 1.03 \\
\hline$* 12$ & $29.7 \pm 1.2$ & 121.2 & $25.8 \pm 1.6$ & 111.0 & 1.09 \\
\hline$* 15$ & $15.3 \pm 2.0$ & 67.5 & $10.2 \pm 1.4$ & 54.0 & 1.25 \\
\hline$* 18$ & $5.1 \pm 0.9$ & 30.6 & $2.6 \pm 0.7$ & 19.2 & 1.59 \\
\hline *21 & $1.5 \pm 0.5$ & $\begin{array}{l}9.9 \\
-\end{array}$ & - & - & - \\
\hline 24 & - & & - & & \\
\hline
\end{tabular}

*Threshold values where differences between Feulgen absorptions are significant at $P \leq 0.05$.

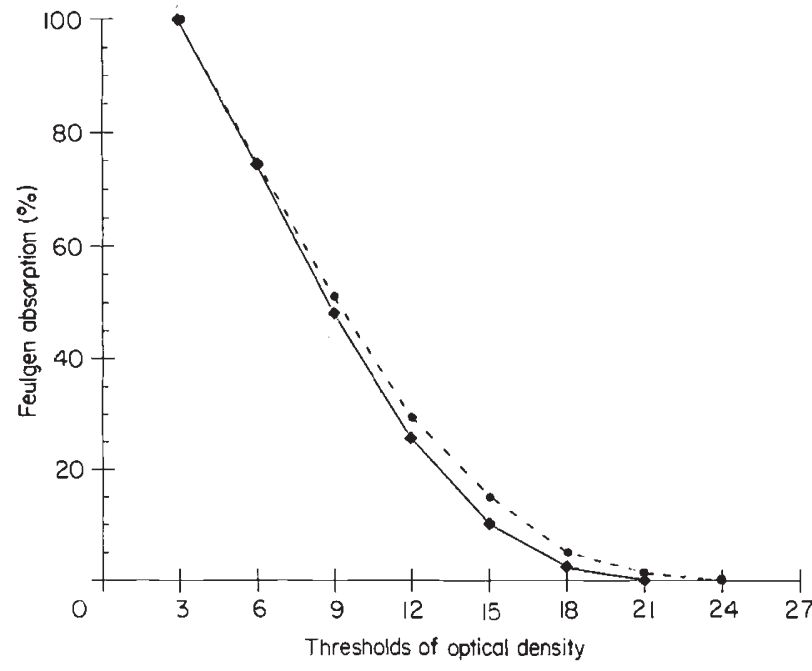

Fig. 1 Percentage of Feulgen absorption at different thresholds of optical density of $4 \mathrm{C}$ interphase nuclei in Dasypyrum villosum. $(\bullet)$ Yellow and $(\bullet)$ brown caryopses.

Chromosome iii. This chromosome is quite constant in both yellow and brown types and is characterized by a large $\mathrm{C}$-band at the telomeres of both short and long arms, which are also apparent after H33258 staining;
Table 4 Areas (arbitrary units) from integral calculation by Simpson's rule; the integral calculation was carried out on the best fit curve obtained from three curves of optical density for each type

\begin{tabular}{lcc}
\hline Caryopses & First area & Second area \\
\hline Yellow & 454.6 & 229.8 \\
Brown & 448.5 & 184.2 \\
\hline
\end{tabular}

sometimes the large C-band on the short arm is resolved into two thin bands. This chromosome resembles B (2H) of Friebe et al. (1987).

Chromosome iv. Similar to chromosome iii, this chromosome can be distinguished because of a slightly larger number of centromeric $\mathrm{C}$-bands. The telomeric band on the short arm sometimes appears as a doublet in brown types. It is similar to chromosome $\mathrm{F}(6 \mathrm{H})$ of Friebe et al.(1987).

Chromosome v. This chromosome is quite constant and characterized by large $\mathrm{C}$-bands at the telomere of the short arm, at the centromeric area, and near the telomere of the long arm; the telomeric and subtelomeric bands fluoresce brightly after H33258 staining. 

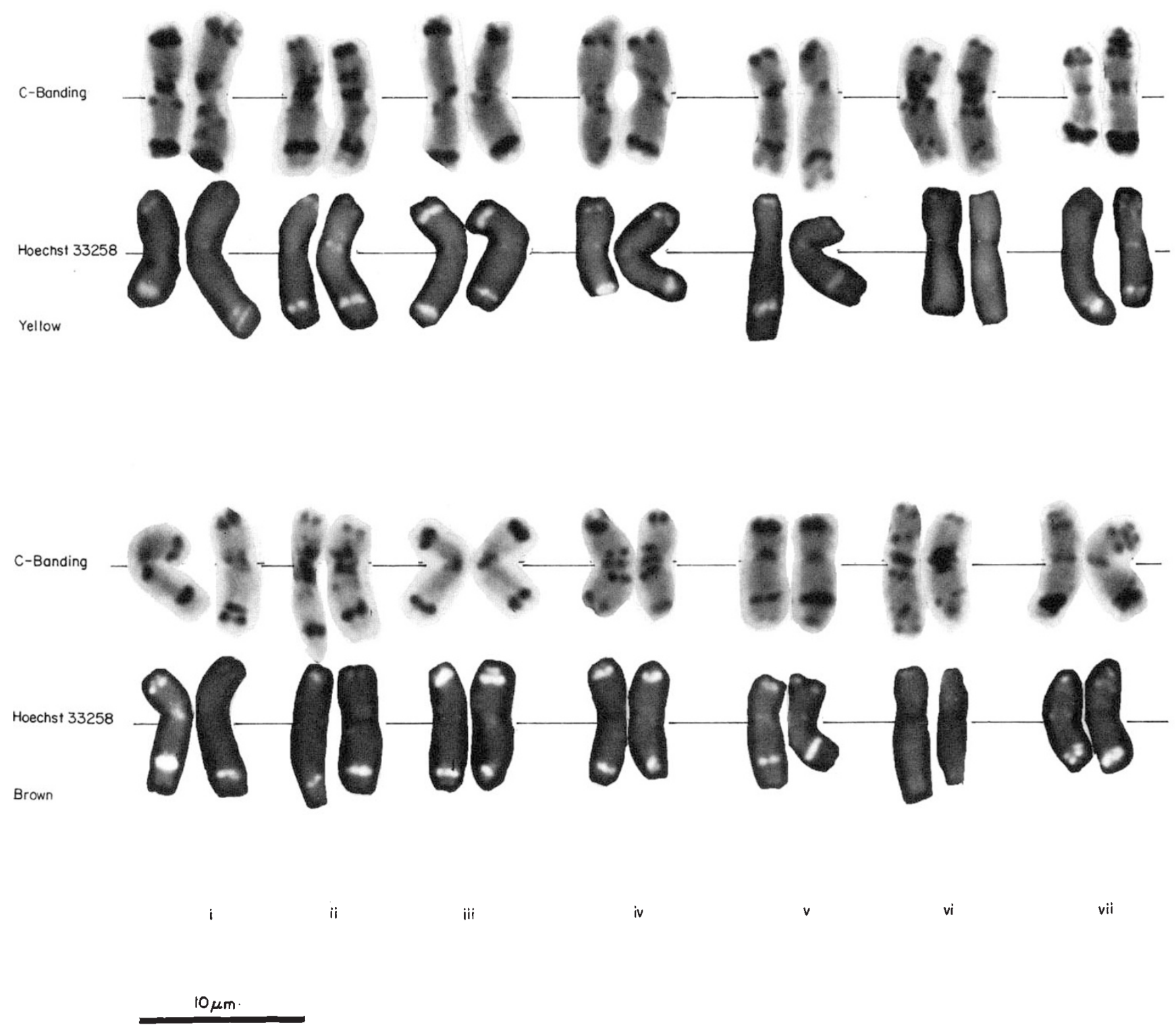

Fig. 2 C-banded and H33258 karyotypes of metaphase chromosomes of root tips from yellow (top two rows) and brown (bottom two rows) types of caryopses. Ten metaphases for each of 20 seedlings of each type were analysed.

A thin telomeric C-band on the long arm is peculiar to the brown type.

Chromosome vi. This chromosome shows little or no heteromorphism. The centromeric region is the site of several C-bands close to each other; the telomere of the short arm is the site of a thin band, while the telomeric region of the long arm presents one block in the yellow type or two blocks in the brown type. No differential staining occurs after H33258 application. It appears to be similar to chromosome $\mathrm{G}(7 \mathrm{H})$ of Friebe et al. (1987).

Chromosome vii. This chromosome is satellited, is variable and heteromorphic - especially in the satellite area (Fig. 4). The satellite presents a telomeric band and one band adjacent to the secondary constriction after C-banding and H33258 staining. The band on the satellite, which is adjacent to the secondary constriction, is observed only on one of the two homologous chromosomes in both the yellow and brown types. The NOR area is positive to CMA and Ag-NOR staining and negative to H33258 and DAPI staining. The CMA and Ag-NOR staining intensity appears to be heteromorphic in the brown types (Fig. $3 \mathrm{~d}$, f). The long arm is quite constant showing two thin telomeric C-bands also observed after H33258 staining. This chromosome resembles A (1H) of Friebe et al. (1987). 

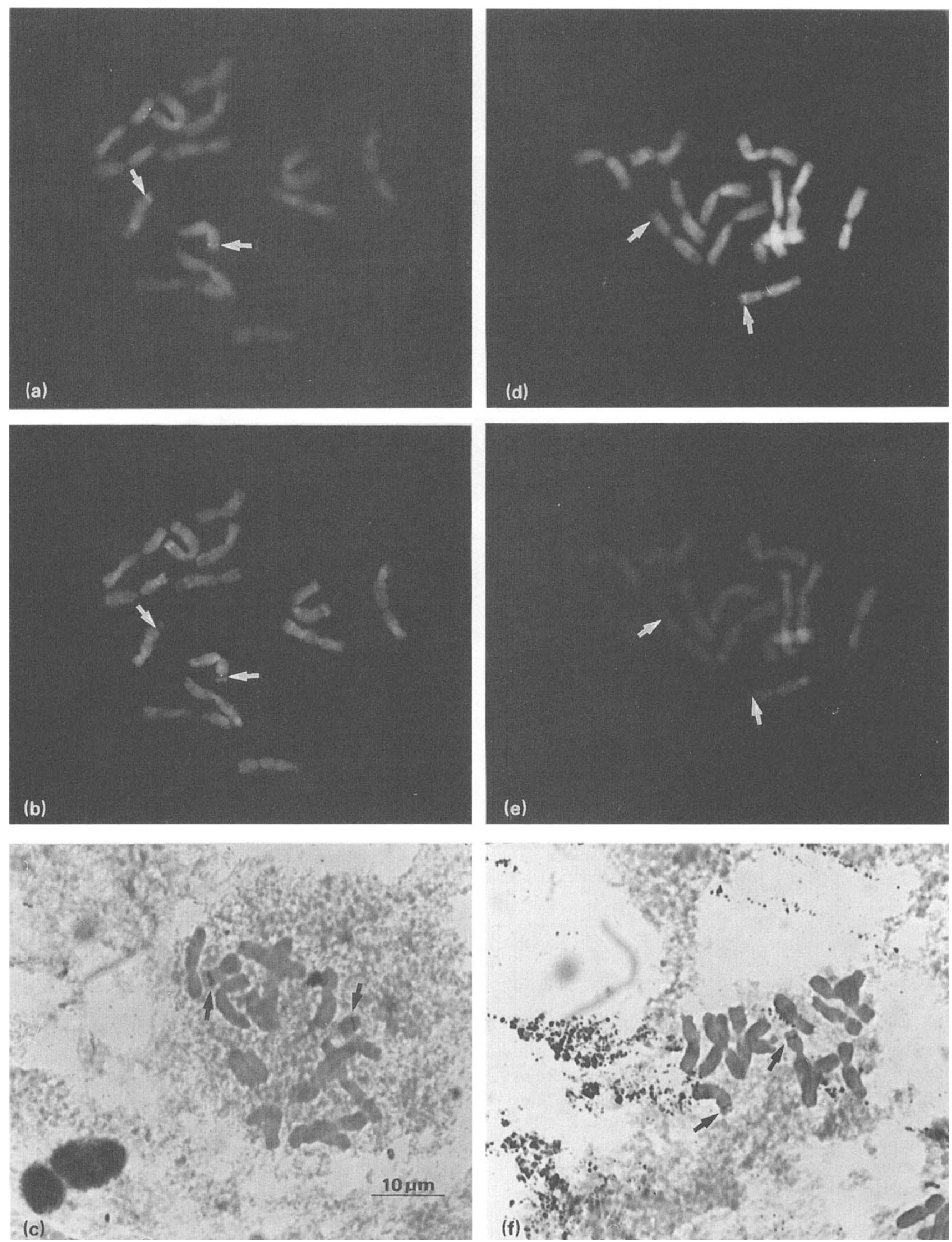

Fig. 3 Metaphases stained with CMA, CMA/DAPI and Ag-NOR techniques: CMA bright bands at the NORs arrowed (filter block E3; a, yellow type; d, brown type); same cells as a and d showing DAPI negative bands at the same sites (filter block A, b, yellow type; e, brown type); silver labelling of NORs for different cells (c, yellow type; f, brown type). 
Fig. 4 Polymorphism of the satellite chromosome (yellow type): in each column are the two homologous chromosomes from the same cell as seen after different staining techniques; the left column shows an idiotype of the chromosome.

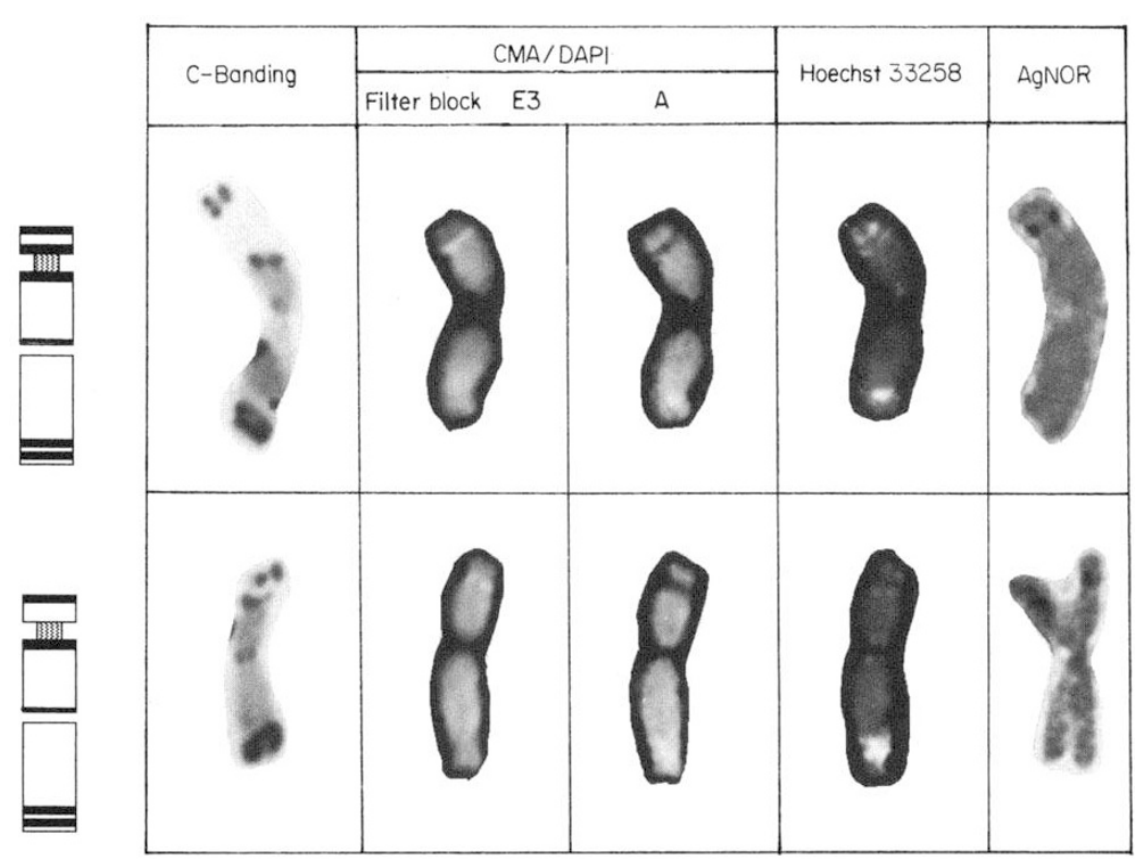

\section{Discussion}

In plants, the term heterochromatin is applied to the chromatin fraction that $(1)$ is more deeply stained after C-banding, (2) may be rich in satellite DNA and (3) is usually transcriptionally inert. C-banding is a quick method to identify heterochromatin cytologically and it is therefore commonly used. Condensed chromatin at interphase can exhibit different arrangements, making it possible to distinguish different types of interphasic nuclear organization (Tschermack-Woess, 1963; Nagl \& Fusenig, 1979; Cionini et al., 1984).

Recently Cremonini et al. (1992) and Ceccarelli et al. (1992) have improved the methods of Patankar \& Ranjekar (1984) and Havelange \& Jeanny (1984) to assess the amount of cytological heterochromatin determined by densitometric analyses of Feulgen absorption at different thresholds of optical density. These analyses were carried out on meristematic cells because the percentage of heterochromatin is higher in meristematic cells than in differentiated ones, indicating underreplication of heterochromatin during differentiation (Bassi, 1990 and references therein).

The determination of nuclear DNA content, which we obtained by Feulgen densitometry, might be subject to some reservations (Greilhuber, 1986, 1988). Nevertheless, since nuclei were analysed in the same early prophase condition, from the same tissues and at the same stage of development, and all squashes were stained together (with $V$. faba squashes used as an internal standard, after pectinase-EDTA treatment), these differences in Feulgen absorption values reflect real differences in the DNA content.

The results of our cytophotometric analyses on the two types of caryopses indicate values of nuclear DNA content that contradict a previous report made by Bennett (1972). The author did not specify which type of kernel and population he analysed; divergences might also be due to the different cytophotometric method, since we used an integrated microdensitometer.

The difference in the organization of nuclear chromatin in the two types of caryopsis is confirmed by the results of measurements taken at different thresholds of optical density. When, for example, the residual Feulgen absorption of brown seeds is 10.2 per cent, the Feulgen absorption in yellow seeds is 15.3 per cent, which means, according to our interpretation, more cytophotometrically determined heterochromatin in the yellow caryopses. Further evidence for this was obtained from the ratios between the areas of each gap of optical density as reported in Table 3 . While the ratio is near 1 at the lower thresholds, at the highest the ratios are 1.25 and 1.59 , confirming that there is more dense chromatin in the meristematic cells of the yellow caryopses.

Chromosome staining techniques have shown that the karyotype of the population examined is variable. $D$. villosum is an outbreeder and therefore a certain degree of variation is expected as a result of the assortment of parents, as previously observed in Secale cereale (Weimarck, 1975). A similar observation was 
made by Friebe et al. (1987) for populations of $D$. villosum of Italian and Greek origin, while he observed that in D. villosum additions to 'Chinese Spring' wheat, no variation was present, probably as a consequence of the selection cycles and inbreeding required to develop those lines.

It is noteworthy that polymorphism occurs for different bands both in yellow and in brown types; bands that are stable in one type may be polymorphic in the other.

It is also rather interesting that on metaphase chromosomes banding techniques do not bring out striking evidence of a variation in heterochromatin amount between yellow and brown types; the small variations observed do not account altogether for the difference in heterochromatin content as cytophotometrically determined.

It is important to remember that the binding of Giemsa to chromatin is non-stoichiometric; therefore, bands with similar appearance could possess different amounts of DNA. Moreover, C-banding and cytophotometry consider cells in different functional stages: in the former, chromosomal heterochromatin represents a level of packaging of DNA into chromosomes, and in the latter, nuclear heterochromatin represents condensed DNA in interphase condition, and differences in heterochromatin amount may reflect differences in genome expression.

Once heterochromatin was considered as a homogeneous component of nuclear chromatin. Now, since heterochromatic areas tend to have dissimilar staining properties, researchers have been forced to define different heterochromatin classes (Filion, 1980; Loidl, 1982; Pignone et al., 1989) that differ mainly in chemical constitution. The results we obtained demonstrate that not all heterochromatin is involved in population diversity. Therefore, it can be hypothesized that different fractions might have a different functional 'tightness', some being more stable and unaffected by population variation, while others are more variable. This could arise through a mechanism which leads to a variability in the amount of repetitive sequences between chromosomes of yellow and brown caryopses (Frediani et al., 1991).

\section{Acknowledgement}

This work was partially supported by a grant from M.U.R.S.T., Rome.

\section{References}

BASSI, P. 1990. Quantitative variations of nuclear DNA during plant development: a critical analysis. Biol. Rev., 65, $185-225$.
BENNETT, M. D. 1972. Nuclear DNA content and minimum generation time in herbaceous plants. Proc. R. Soc. London Ser. B., 181, 109-135.

BERLYN, G. P., DHILloN, S. S. AND MIKSCHE, J. P. 1979. Feulgen cytophotometry of pine nuclei. II. Effect of pectinase used in cell separation. Stain Technol., 54, 201-204.

BLANCO, A. AND SIMEONE, R. 1988. Use of Dasypyrum villosum (L.) Candargy in durum wheat improvement. Proc. $3 r d$ Int. Symp. Durum Wheat, Foggia, Italy, pp. 215-228.

BLOOM, S. E. AND GOODPASTURE, C. 1976. An improved technique for selective silver staining of nuclear organizer regions in human chromosomes. Hum. Genet., 34, 199-206.

CECCARELLI, M., FALISTOCCO, E. AND CIONINI, P. G. 1992. Variation of genome size and organization within hexaploid Festuca arundinacea. Theor. Appl. Genet., 83, 273-278.

CIONINI, P. G., CREMONINI, R. AND BASSI, P. 1984. Highly repeated DNA sequences and the structural organization of plant cell nuclei. Ann. Botanica, XLII, 29-44.

CREMONINI, R., FUNARI, S. AND MAZZUCA, S. 1992. Cytology of Vicia species: nuclear structure, karyological analysis and DNA content. Chromatin, 1, 135-146.

DE GARA, L., PACIOLla, C., LISO, R., STEFANI, A. AND ARRIGONI, O. 1991. Correlation between ascorbate peroxidase activity and some anomalies of seedlings from aged caryopses of Dasypyrum villosum (L.) Borb. J. Plant Physiol., 137, 697-700.

DE PACE, C., MONTEBOVE, L., DELRE, V., JAN, C. C., QUALSET, C. O. AND SCARASCIA MUGNOZZA, G. T. 1988. Biochemical versatility of amphiploids derived from crossing Dasypynum villosum Candargy and wheat: genetic control and phenotypical aspects. Theor. Appl. Genet., 76, 513-529.

Della GatTa, C., TANZARElla, O. A., RESTA, P. AND Blanco, A. 1984. Protein content in a population of Haynaldia villosa and electrophoretic pattern of the amphiploid Triticum durum $\times$ Haynaldia villosa. Proc. Workshop 'Breeding methodologies on durum wheat and Triticale', Viterbo, Italy, pp. 49-52.

FILION, W. G. 1980. Chromosome banding in plants: techniques and applications. Can. J. Genet. Cytol., 22, 662-663.

FREDERIKSEN, S. 1991. Taxonomic studies in Dasypyrum (Poaceae). Nord. J. Bot., 11, 135-142.

FREDIANI, M., CREMONINI, R., DE PACE, C., DEL RE, V., SCARASCIA MUGNOZZA, G. T. AND CIONIN1, P. G. 1991. Localizzazione cromosomica di una sequenza di DNA ripetuta di Dasypyrum villosum e sua instabilità quantitativa nel genoma. Giorn. Bot. Ital., 125, 212.

FRIEBE, B., CERMENO, M. C. AND ZELLER, F. J. 1987. C-banding polymorphism and the analysis of nucleolar activity in Dasypyrum villosum (L.) Candargy, its added chromosomes to hexaploid wheat and the amphiploid Triticum dicoccum - D. villosum. Theor. Appl. Genet., 73, 337-342.

GAlasso, I. AND PIGNONE, D. 1991. Vigna vexillata (L.) A. Richard and Vigna unguiculata (L.) Walp.: due cariotipi a confronto. Atti XXXV Convegno Annuale S. I. G. A., p. 90. GILL, B. S. 1981. Evolutionary relationships based on heterochromatin bands in six species of the Triticinae. J. Hered., 72, 391-394. 
GIRALDEZ, R., CERMENo, M. C. AND ORELlanA, J. 1979. Comparison of C-banding pattern in chromosomes of inbred lines and open pollinated varieties of rye. Z. Pflanzenzuchtg., 83, 40-48.

GREILHUBER, J. 1986. Severely distorted Feulgen-DNA amounts in Pinus after non-additive fixations as a result of meristematic self-tanning with vacuole contents. Can. J. Genet. Cytol., 28, 409-415.

GREILHUBER, J. 1988. 'Self-tanning' a new and important source of stoichiometric error in cytophotometric determinations of nuclear DNA content in plants. Plant Syst. Evol., 158, 87-96.

GRILLI, I., STEFANI, A. AND ONNIS, A. 1988. Endosperm proteins and cytogenetics of Dasypyrum villosum (L.) P. Candargy. Genet. Agr. XLII (1), 77.

haVElange, A. AND JEANNY, J. C. 1984. Changes in density of chromatin in the meristematic cells in Synapis alba during transition to flowering. Protoplasma, 122, 222-232.

INNOCENTI, A. M. AND BITONTI, M. B. 1983. Different duration of the mitotic cycle in seedlings from brown and black caryopses of Haynaldia villosa Schur. Caryologia, 36, 27-32.

KNOTT, D. R. 1987. Transferring alien genes to wheat. In: Heine, E. G. (ed.) Wheat and Wheat Improvement, 2nd edn, pp. 462-471. Madison, WI.

LINDE-LAURSEN, I. AND FREDERIKSEN, s. 1991. Comparison of the Giemsa C-banded karyotypes of Dasypyrum villosum $(2 \mathrm{x})$ and $D$. breviaristatum $(4 \mathrm{x})$ from Greece. Hereditas, 114, 237-244.
LOIDL, J. 1982. Some features of heterochromatin in wild Allium species. Plant Syst. Evol., 143, 117-131.

MELETTI, P. AND ONNIS, A. 1961. Variazioni sulle caratteristiche delle cariossidi in alcune Graminacee compreso il fenomeno della bianconatura in Triticum durum Desf. Nuovo Giorn. Bot. Ital., 68, 79-88.

NAGL, W. AND FUSENIG, H. P. 1979. Types of chromatin organization in plant cell nuclei. Plant Syst. Evol. (Suppl.) 2, 221-233.

PATANKAR, S. AND RANJEKAR, P. K. 1984. Condensed chromatin and its underreplication during root differentiation in leguminosae. Plant Cell Rep., 3, 250-253.

PIGNONE, D., ATTOLICO, M. AND CIFARELLI, S. 1989. Differential staining of wheat chromosomes with an hydrolytic technique. Caryologia, 42, 49-56.

SEARS, E. R. 1953. Addition of the genome of Haynaldia villosa to Triticum aestivum. Am. J. Bot., 40, 168-174.

SEGUY, E. 1936. Code Universal des Colours. Lechevalier, P.(ed), Paris.

STEFANI, A. AND ONNIS, A. 1983. Contributo alla conoscenza delle caratteristiche fenologiche di popolazioni naturali di Dasypyrum villosum (L.) P. Candargy. Inf. Bot. Ital., 15, 213-224.

TSCHERMACK-woEss, E. 1963. Strukturtypen der Ruhekerne von Pflanzen und Tieren. Protoplasmatologia, V/1 Springer, Vienna.

WEIMARCK, A. 1975. Heterochromatin polymorphism in the rye karyotype as detected by the giemsa C-banding technique. Hereditas, 79, 293-300. 